\title{
Single-particle investigation of summertime and wintertime Antarctic sea spray aerosols using low- $Z$ particle EPMA, Raman microspectrometry, and ATR-FTIR imaging techniques
}

\author{
Hyo-Jin Eom ${ }^{1}$, Dhrubajyoti Gupta ${ }^{1}$, Hye-Rin Cho ${ }^{1}$, Hee Jin Hwang ${ }^{2}$, Soon Do Hur ${ }^{2}$, Yeontae Gim ${ }^{3}$, and Chul-Un Ro \\ ${ }^{1}$ Department of Chemistry, Inha University, Incheon, Republic of Korea \\ ${ }^{2}$ Polar Climate Change Research Division, Korea Polar Research Institute, Incheon, Republic of Korea \\ ${ }^{3}$ Arctic Research Center, Korea Polar Research Institute, Incheon, Republic of Korea
}

Correspondence to: Chul-Un Ro (curo@inha.ac.kr)

Received: 5 July 2016 - Published in Atmos. Chem. Phys. Discuss.: 1 August 2016

Revised: 13 October 2016 - Accepted: 21 October 2016 - Published: 9 November 2016

\begin{abstract}
Two aerosol samples collected at King Sejong Korean scientific research station, Antarctica, on 9 December 2011 in the austral summer (sample S1) and 23 July 2012 in the austral winter (sample S2), when the oceanic chlorophyll $a$ levels on the collection days of the samples were quite different, by $\sim 19$ times $\left(2.46\right.$ vs. $0.13 \mu \mathrm{g} \mathrm{L}^{-1}$, respectively), were investigated on a single-particle basis using quantitative energy-dispersive electron probe X-ray microanalysis (ED-EPMA), called low- $Z$ particle EPMA, Raman microspectrometry (RMS), and attenuated total reflection Fourier transform infrared (ATR-FTIR) imaging techniques to obtain their characteristics based on the elemental chemical compositions, molecular species, and mixing state. X-ray analysis showed that the supermicron summertime and wintertime Antarctic aerosol samples have different elemental chemical compositions, even though all the individual particles analyzed were sea spray aerosols (SSAs); i.e., the contents of $\mathrm{C}, \mathrm{O}, \mathrm{Ca}, \mathrm{S}$, and $\mathrm{Si}$ were more elevated, whereas $\mathrm{Cl}$ was more depleted, for sample $\mathrm{S} 1$ than for sample S2. Based on qualitative analysis of the chemical species present in individual SSAs by the combined application of RMS and ATR-FTIR imaging, different organic species were observed in samples $\mathrm{S} 1$ and $\mathrm{S} 2$; i.e., $\mathrm{Mg}$ hydrate salts of alanine were predominant in samples $\mathrm{S} 1$ and $\mathrm{S} 2$, whereas $\mathrm{Mg}$ salts of fatty acids internally mixed with $\mathrm{Mg}$ hydrate salts of alanine were significant in sample S2. Although $\mathrm{CaSO}_{4}$ was observed significantly in both samples $\mathrm{S} 1$ and $\mathrm{S} 2$, other inorganic species, such as $\mathrm{Na}_{2} \mathrm{SO}_{4}, \mathrm{NaNO}_{3}, \mathrm{Mg}\left(\mathrm{NO}_{3}\right)_{2}, \mathrm{SiO}_{2}$, and $\mathrm{CH}_{3} \mathrm{SO}_{3} \mathrm{Mg}$, were observed more significantly in sam-
\end{abstract}

ple S1, suggesting that those compounds may be related to the higher phytoplankton activity in summer.

\section{Introduction}

As more than $70 \%$ of the Earth's surface is covered by ocean, sea spray aerosols (SSAs) make a dominant contribution to the total aerosol load in the air (Quinn et al., 2015). The influence of nascent SSAs on the Earth's radiative balance, either directly by scattering light or indirectly by acting as cloud droplets or ice nuclei, needs to be understood to better predict the additional anthropogenic effects on SSAs (Ault et al., 2013a). Recently, it was suggested that SSAs mixed with organic matter occurring at the ocean surface can have a significant influence on the Earth's climate change (Wang et al., 2015). In addition, an understanding of the nascent SSA properties in terms of the physical, chemical, and biological processes in the ocean surface is required to reduce the current uncertainties for climate models (Prather et al., 2013).

SSAs are generated by bubbles bursting at the sea surface, where submicron and supermicron SSAs are believed to be formed mostly from film drops and jet drops, respectively (Quinn et al., 2014, 2015; Wang et al., 2015). Submicron nascent SSAs were reported to have more enriched organic species and less inorganic salts than the supermicron nascent SSAs (Ault et al., 2013b; Prather et al., 2013; Wang et al., 2015). Although the molecular species of the organic matter in nascent SSAs are unknown, a recent mesocosm ex- 
periment showed that submicron SSAs were enriched with aliphatic-rich organic species, whereas supermicron SSAs contained more oxidized organic species (Wang et al., 2015). As organic and inorganic matter in seawater could be produced through the biological food web, the chemical compositions in nascent SSAs would be interrelated to the biological activity in seawater. On the other hand, there have been disputes regarding the correlation between the biological activity in the ocean and SSA organic matter in the marine boundary layer. Some studies reported positive correlations between the levels of chlorophyll $a$, which is an indicator of the biological activity in the seawater, and organic matter in SSAs (Prather et al., 2013; Hu et al., 2013; Rinaldi et al., 2010; O'Dowd et al., 2004), whereas some showed no correlation between them (Quinn et al., 2014; Bates et al., 2012). In addition, it was claimed that the chlorophyll $a$ level showed a complicated correlation with the organic matters in nascent SSAs, and the bacterial enzyme activities should also be considered to better understand the overall generation and temporal variations of organic matter (Wang et al., 2015), strongly suggesting the necessity for further studies.

The Antarctic region, which is isolated from anthropogenic sources, is one of the few pristine places to study natural SSAs with a minimal anthropogenic influence (Maskey et al., 2011). A major constituent in the Antarctic troposphere is nascent SSAs (Hara et al., 2012; Maskey et al., 2011) and their chemical compositions can be altered through heterogeneous reactions with $\mathrm{SO}_{4}^{2-}$ and $\mathrm{CH}_{3} \mathrm{SO}_{3}^{-}$during the summer (Hara et al., 2014). Some studies on the characterization and seasonal cycles of different aerosol species at various Antarctic locations, such as McMurdo (Ross Island), Aboa (Queen Maud Land), Syowa (East Ongul Island), Dome Fuji (Queen Maud Land), O'Higgins (Chile), Admiralty Bay (King George Island), and Mizuho (Atka Bay) stations, have been carried out, and bulk and single-particle analytical techniques showed that the sea salts and sulfurcontaining species were the most abundant constituents in Antarctic aerosol samples (Hara et al., 2013, 2012; Maskey et al., 2011; Préndez et al., 2009; Biancato et al., 2006; Hara et al., 2006; Kerminen et al., 2000; Shaw, 1988). In this study, two Antarctic aerosol samples collected on 9 December 2011 in the austral summer (sample S1) and 23 July 2012 in the austral winter (sample S2), having a drastic contrast in the oceanic chlorophyll $a$ levels on the collection days of the samples, were characterized on a single-particle basis using quantitative energy-dispersive electron probe X-ray microanalysis (ED-EPMA), called low- $Z$ particle EPMA, Raman microspectrometry (RMS), and attenuated total reflection Fourier transform infrared (ATR-FTIR) imaging. In the present study, low- $Z$ particle EPMA was applied to investigate the elemental compositional contrast between the summertime and wintertime samples, and two vibrational spectroscopic techniques, such as RMS and ATR-FTIR imaging, were employed on a single-particle basis to identify the organic and inorganic molecular species present in Antarctic aerosol samples, clearly revealing the different chemical features between two samples.

\section{Experimental section}

\subsection{Samples}

Aerosol samples were collected at a Korean scientific research station in the Antarctic: King Sejong station $\left(62^{\circ} 13^{\prime} \mathrm{S}\right.$, $58^{\circ} 47^{\prime} \mathrm{W}$ ), which is located at King George Island, Chile (see Fig. S1 of the Supplement). King George Island in the Southern Ocean is $120 \mathrm{~km}$ off the coast of Antarctica, and is dominated by pervasive ice caps, with more than $90 \%$ of the island being glaciated. This study examined two aerosol samples S1 and S2 collected on 9 December 2011 in the austral summer and 23 July 2012 in the austral winter, respectively, when the oceanic chlorophyll $a$ levels on the collection days of the samples were quite different, by $\sim 19$ times (2.46 vs. $0.13 \mu \mathrm{g} \mathrm{L}{ }^{-1}$, respectively). The oceanic chlorophyll $a$ levels for water samples collected daily from nearby oceanic water were determined using a fluorometer (TD 700, Turner Design, USA). The detailed description for chlorophyll $a$ determination is given elsewhere (Schloss et al., 2014; Lee et al., 2015). The aerosol samples were collected on $\mathrm{Al}$ foil substrates (Sigma-Aldrich, $99.8 \%$ purity) using a three-stage cascade impactor ( $\mathrm{PM}_{10}$ Impactor, Dekati Inc.) during daytime at temperatures $T=1.1$ to 2.1 and -1.9 to $-1.5^{\circ} \mathrm{C}$ and relative humidity $\mathrm{RH}=94.1-94.5$ and $87.6-92.1 \%$ for samples S1 and S2, respectively. The impactor had aerodynamic cut sizes of $10,2.5$, and $1 \mu \mathrm{m}$ for stages 1,2 , and 3, respectively, at a $10 \mathrm{~L} \mathrm{~min}^{-1}$ sampling flow, and individual particles collected at stages 2 and $3\left(\mathrm{PM}_{2.5-10}\right.$ and $\mathrm{PM}_{1.0-2.5}$ fractions with the size ranges of $2.5-10$ and $1-2.5 \mu \mathrm{m}$, respectively) were examined.

Three-day (72 h) backward air-mass trajectories were obtained using the Hybrid Lagrangian Single-Particle Integrated Trajectory (HYSPLIT) model from the NOAA Air Resources Laboratory's web server (http://www.arl.noaa. gov/ready/hysplit4.html). The back-trajectories for samples S1 and S2 show that the air masses at heights of 500, 1000 , and $1500 \mathrm{~m}$ above sea level, which originated from the Pacific Ocean, travelled over the Pacific Ocean and passed over Chile, respectively (see Fig. S1 of the Supplement).

\subsection{Low- $Z$ particle EPMA measurement and data analysis}

Low- $Z$ particle EPMA measurements were carried out by scanning electron microscopy (JSM-6390, JEOL) equipped with an Oxford Link SATW ultrathin window energydispersive X-ray (EDX) detector, which has a spectral resolution of $133 \mathrm{eV}$ for $\mathrm{Mn} \mathrm{K} \alpha \mathrm{X}$-rays. The X-ray spectra and elemental X-ray maps were recorded using INCA Energy software. An accelerating voltage of $10 \mathrm{kV}$, a beam current of $0.5 \mathrm{nA}$, and a typical measuring time of $20 \mathrm{~s}$ were used for 
the X-ray spectral data acquisition using area mode, where the X-ray signals were obtained by scanning electron beam over the entire area of each particle. The net X-ray intensities for the chemical elements were obtained by a nonlinear, least-square fit of the spectra collected using the AXIL program (Vekemans et al., 1994). The elemental concentrations of the individual particles were determined from their X-ray intensities using a Monte Carlo calculation combined with reverse successive approximations (Ro et al., 2003). For the $\mathrm{X}$-ray mapping measurements, an accelerating voltage and beam current are the same as the area-mode measurements, except for a typical measuring time of $30 \mathrm{~min}$. A more detailed discussion of the EPMA measurement conditions can be found elsewhere (Ro et al., 2005, 1999).

\subsection{RMS measurements}

The particles collected on Al foil were mounted on the microscope stage of a confocal Raman microspectrometer (XploRA, Horiba Jobin Yvon) equipped with a $100 \times, 0.9$ numerical aperture objective (Olympus). Raman point and mapping measurements were carried out under ambient conditions. Optical images of the particles for relocation were obtained using a video camera. Raman scattering was excited at the $532 \mathrm{~nm}$ wavelength using an air-cooled diode laser and detected with a multichannel air-cooled chargecoupled device (CCD) at an $1800 \mathrm{gr} \mathrm{mm}^{-1}$ grating. The excitation laser power delivered to the individual particles was approximately $3 \mathrm{~mW}$ using a controlled confocal hole of $300 \sim 500 \mu \mathrm{m}$ and a slit, $100 \mu \mathrm{m}$ in diameter. The spectral ranges of $100-4000 \mathrm{~cm}^{-1}$ were performed with a $5 \mathrm{~s}$ acquisition time and five-time accumulation for each measurement. The spectral resolution was $1.8 \mathrm{~cm}^{-1}$ and the spot size of the laser beam at the sample was estimated to be $\sim 1 \mu \mathrm{m}^{2}$. The XYZ computer-controlled Raman mapping was performed by obtaining the Raman spectra in point-by-point XY scanning mode with a $1 \mu \mathrm{m}$ step and a $5 \mathrm{~s}$ integration time per pixel. The spectra and images were acquired using Labspec6 software. A more detailed discussion of the RMS measurement conditions for single-particle analysis can be found elsewhere (Sobanska et al., 2012; Eom et al., 2013; Jung et al., 2014).

\subsection{ATR-FTIR imaging measurements}

The ATR-FTIR imaging measurements were performed using a Perkin Elmer Spectrum 100 FTIR spectrometer interfaced to a Spectrum Spotlight 400 FTIR microscope. An ATR accessory using a germanium hemispherical IRE crystal, $600 \mu \mathrm{m}$ in diameter, was used for ATR imaging. The ATR accessory was mounted on the $\mathrm{X}-\mathrm{Y}$ stage of the FTIR microscope and the IRE crystal was made to come into contact with the sample through a force lever. A spatial resolution of $3.1 \mu \mathrm{m}$ at $1726 \mathrm{~cm}^{-1}(\lambda=5.79 \mu \mathrm{m})$ is achievable (Van Dalen et al., 2007). A $16 \times 1$ pixel mercury cadmium telluride (MCT) array detector was used to obtain the FTIR images with a pixel size of $1.56 \mu \mathrm{m}$. For each pixel, an ATRFTIR spectrum, ranging from 680 to $4000 \mathrm{~cm}^{-1}$ with a spectral resolution of $4 \mathrm{~cm}^{-1}$, was obtained from eight interferograms, which were co-added and Fourier-transformed. The position of the crystal on the sample was determined using an optical microscope equipped with a light-emitting diode and a CCD camera, which allowed relocation of the same single particles that had been analyzed using RMS before ATR-FTIR imaging. Spectral data processing was performed using Perkin Elmer Spectrum IMAGE software. A more detailed discussion of the ATR-FTIR imaging measurement conditions for single-particle analysis can be found elsewhere (Song et al., 2010, 2013; Jung et al., 2014).

\section{Results and discussion}

\subsection{Single-particle characterization of the summertime and wintertime Antarctic SSAs using low- $Z$ particle EPMA}

Figure 1 presents typical secondary electron images (SEIs) of the individual particles on two $\mathrm{PM}_{2.5-10}$ (stage 2) samples collected in the austral summer and winter, where the chemical species comprising each particle, determined from X-ray spectral data, is indicated. All the particles on the images are of a marine origin, having major $\mathrm{Na}$ and $\mathrm{Cl}$ contents with small quantities of $\mathrm{C}, \mathrm{O}, \mathrm{Mg}, \mathrm{K}, \mathrm{Ca}, \mathrm{S}$, and/or Si. Overall, approximately 600 particles of samples S1 and S2 examined by low- $Z$ particle EPMA were of a marine origin. $\mathrm{Na}, \mathrm{Mg}$, $\mathrm{Cl}, \mathrm{S}, \mathrm{C}$, and $\mathrm{O}$ were present in all the particles, whereas $\mathrm{K}$, $\mathrm{Ca}$, and $\mathrm{Si}$ were observed more frequently in the summertime sample S1 than in the wintertime sample S2 $(93.6 \%$ vs. $79.4 \%$ relative encountering frequencies for $\mathrm{K} ; 93.9 \%$ vs. $75.5 \%$ for $\mathrm{Ca}$; and $70.1 \%$ vs. $0.7 \%$ for $\mathrm{Si}$, respectively, where the relative encountering frequency (in \%) for a certain element is defined as the number of particles containing the element divided by the total number of particles analyzed for a sample.). In particular, $\mathrm{Si}$ is present exclusively in sample S1, which might be a good indicator of the phytoplankton influence on the nascent SSAs.

As ambient relative humidity $(\mathrm{RH})$ at the sampling times was higher than $87.6 \%$ and the efflorescence RHs (ERHs) of the inorganic sea salt components (e.g., ERHs of $\mathrm{NaCl}$ and $\mathrm{CaSO}_{4}$ are $\sim 45-47$ and $\sim 80-90 \%$, respectively; Gupta et al., 2015; Schindelholz et al., 2014; Xiao et al., 2008), the SSAs would be collected as aqueous droplets at the time of collection. Once exposed at a low RH, e.g., by being either handled under the dry ambient conditions or placed in the vacuum chamber of SEM, they would crystallize fractionally, resulting in their heterogeneous mixing states, as shown in Fig. 1, having bright and crystalline solids, segregated and somewhat dark regions, and elongated rods (indicated by the yellow arrows in Fig. 1), which are more distinctive for the 

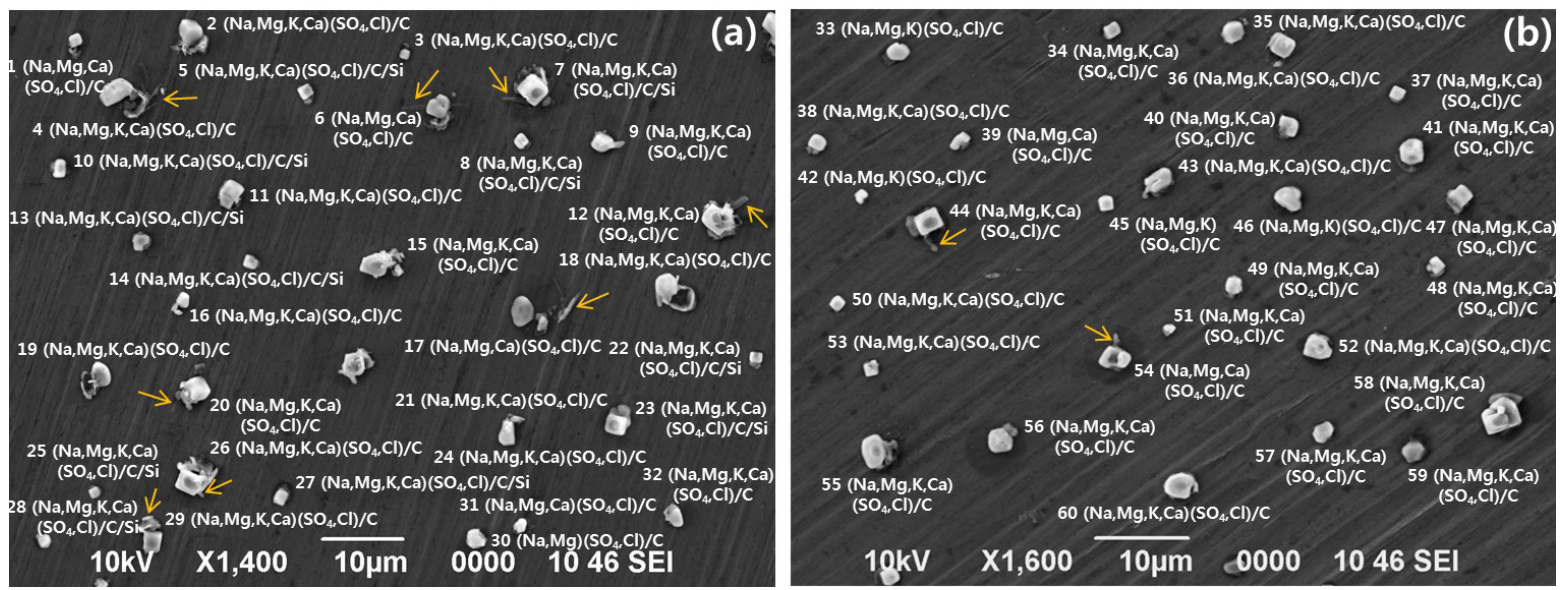

Figure 1. Typical secondary electron images (SEIs) of aerosol particles at stages 2 of the austral (a) summertime and (b) wintertime samples collected at King Sejong station, Antarctica.

summertime particles. The fractional crystallization of SSAs has also been reported (Ault et al., 2013a; Hara et al., 2013, 2014). To determine the chemical species of the crystalline solids, dark regions, and rods, elemental X-ray and molecular Raman mapping measurements were performed on the same individual SSA particles. Figure 2 presents the SEIs and molecular Raman and elemental X-ray map images of two typical summertime and wintertime SSA particles. As Raman-inactive $\mathrm{NaCl}$ and $\mathrm{MgCl}_{2}$ species cannot generate Raman signals, Raman mapping was performed to determine the spatial distributions of $\mathrm{CaSO}_{4}$ (using a Raman signal in the $1000-1020 \mathrm{~cm}^{-1}$ range), $\mathrm{Na}_{2} \mathrm{SO}_{4}$ (using a Raman signal in the $985-995 \mathrm{~cm}^{-1}$ range), and organic species (using a Raman signal in the $2800-3000 \mathrm{~cm}^{-1}$ range). X-ray mapping images of $\mathrm{Na}, \mathrm{Mg}, \mathrm{Ca}, \mathrm{Cl}, \mathrm{S}, \mathrm{C}$, and $\mathrm{O}$ are overlaid in different colors on the SEIs. Molecular Raman images look broader than elemental X-ray images as the spatial resolution of Raman mapping $(\sim 1 \mu \mathrm{m})$ is larger than that of $\mathrm{X}$-ray mapping $(\sim 0.1 \mu \mathrm{m})$. Especially, Raman images for organic species look more spread than C X-ray map images as the low energy $\mathrm{C} \mathrm{X}$-rays generated from underneath are not often detected due to the strong absorption by solid particles sitting above. Nonetheless, the combined Raman and X-ray map image data of Fig. 2a clearly indicate that the upper bright solid (region 1, notated on the SEI of Fig. 2a) of the summertime SSA particle is composed of $\mathrm{NaCl}$, the bottom-right region 3 is a mixture of $\mathrm{MgCl}_{2}$ and organic species (having a somewhat dark appearance due to the low secondary electron yield of organic species), and the two elongated rods are of a mixture of $\mathrm{CaSO}_{4}$ and $\mathrm{Na}_{2} \mathrm{SO}_{4}$. The wintertime SSA particle in Fig. $2 \mathrm{~b}$ is composed of $\mathrm{NaCl}$ (at region 1) and the mixture of $\mathrm{MgCl}_{2}$ and organic species (at region 2). As $\mathrm{C}$ and $\mathrm{O}$ are overlapping in their X-ray maps of Fig. 2, the organic species appear to contain a significant amount of oxygen. Figure 3 shows the X-ray spectra and elemental atomic concentrations obtained from the entire regions of the summertime and win- (a)
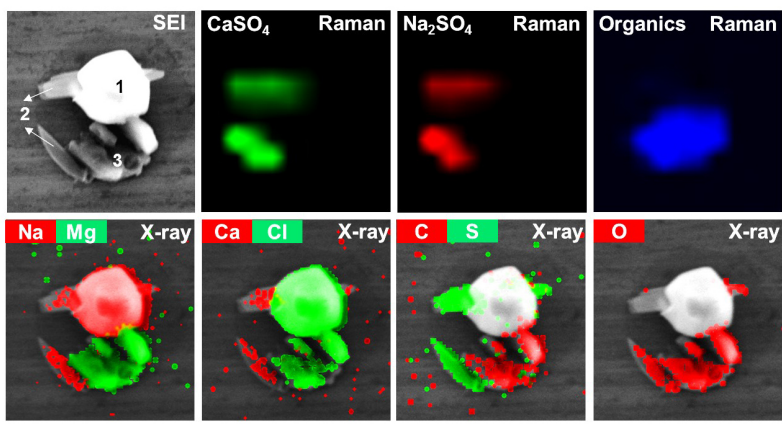

(b)
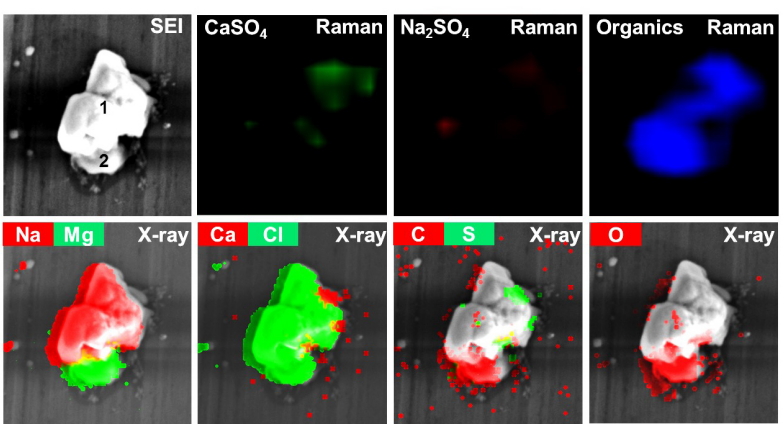

Figure 2. Secondary electron, molecular Raman map and elemental X-ray map (overlaid on SEIs) images of two typical (a) summertime and (b) wintertime SSAs.

tertime particles using area-mode $\mathrm{X}$-ray data acquisition. The summertime particle contains more $\mathrm{C}, \mathrm{O}, \mathrm{Si}, \mathrm{S}$, and $\mathrm{Ca}$ than the wintertime particle. As the amount of sulfate (by assuming all the sulfur exists as sulfate) for the summertime particle is larger than that of $\mathrm{Ca}$, the sulfate first crystallized as $\mathrm{CaSO}_{4}$, and the remaining sulfate crystallized as $\mathrm{Na}_{2} \mathrm{SO}_{4}$, resulting in the formation of elongated rods composed of a mixture of $\mathrm{CaSO}_{4}$ and $\mathrm{Na}_{2} \mathrm{SO}_{4}$. For the wintertime particle, $\mathrm{CaSO}_{4}$ was observed weakly in the upper-right region because of the low sulfate content. 

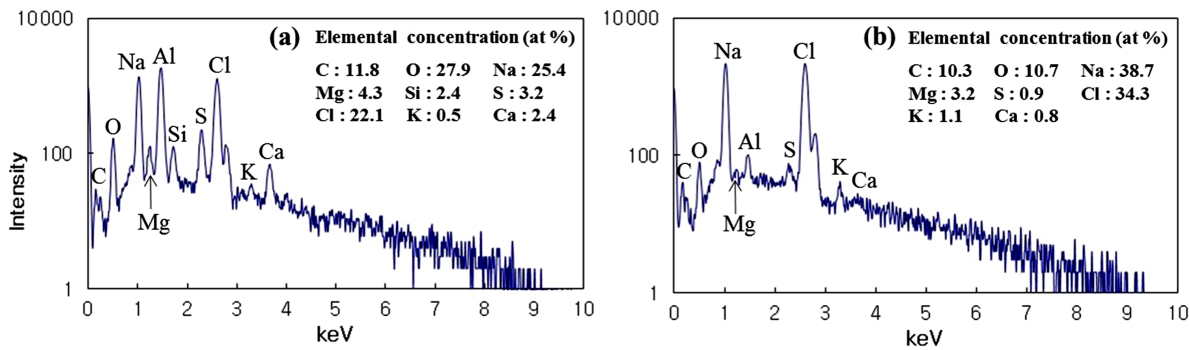

Figure 3. X-ray spectra and elemental atomic concentrations (in atomic \%) of (a) the summertime and (b) wintertime SSA particles shown in Fig. 2.

Table S1 in the Supplement shows the mean elemental concentrations for a total of $\sim 600$ individual particles in $\mathrm{PM}_{1.0-2.5}$ and $\mathrm{PM}_{2.5-10}$ fractions of the summertime and wintertime samples, obtained by low- $Z$ particle EPMA. As all the particles analyzed in these samples are of a marine origin, the mean atomic concentrations of $\mathrm{Na}$ and $\mathrm{Cl}$ are largest (ranging in 25.2-28.3 and 24.8-29.2\%, respectively), followed by high $\mathrm{C}$ and $\mathrm{O}$ concentrations (18.8-27.1 and 17.3-19.5\%, respectively), compared to those of $\mathrm{Mg}, \mathrm{Si}, \mathrm{S}$, $\mathrm{K}$, and $\mathrm{Ca}$, which are in the range $0.0-2.9 \%$. Based on the mean elemental weight concentrations, the $\mathrm{C}$ and $\mathrm{O}$ contents were smaller based on the mean atomic concentrations, even though they were still considerable (9.6-14.6 and 12.0$13.6 \%$, respectively). On the other hand, the organic contents on a molecular basis would be smaller than the elemental $\mathrm{C}$ contents, but the molecular organic content could not be estimated because the organic molecular species in SSAs have not been identified clearly (Ault et al., 2013b; Laskina, 2015; Quinn et al., 2015). An interesting observation was that all the supermicron Antarctic SSAs, both in the summertime and wintertime samples, were a mixture of inorganic and organic species.

To better examine the chemical compositional contrast between samples S1 and S2, Table 1 lists the mean elemental concentration ratios to $\mathrm{Na}$ for individual particles together with those for bulk seawater. The atomic concentration ratios of $\mathrm{C}, \mathrm{O}, \mathrm{Si}, \mathrm{S}$, and $\mathrm{Ca} ; \mathrm{Cl}$; and $\mathrm{Mg}$ and $\mathrm{K}$ for the summertime sample were higher and lower than and similar to those of the wintertime sample, respectively (also see Fig. S2, which clearly shows different distributions of individual particles having specific elemental concentration ratios between the summertime and wintertime samples), indicating that $\mathrm{C}, \mathrm{O}$, $\mathrm{Si}, \mathrm{S}$, and $\mathrm{Ca}$; and $\mathrm{Cl}$ are enriched and depleted in the summertime sample, respectively. In addition, those enriched and depleted elements have higher and lower concentration ratios than the bulk seawater ratios, respectively.

As the $[\mathrm{C}] /[\mathrm{Na}]$ ratios for both samples were high compared to the bulk seawater $[\mathrm{C}] /[\mathrm{Na}]$ ratio, even the supermicron Antarctic SSAs contain significantly enriched organic species. The [C] / [Na] ratios of sample S1 were higher than those of sample S2, suggesting that the higher organic matter is related to the higher phytoplankton activities, and those for particles in the $\mathrm{PM}_{1.0-2.5}$ fractions of samples $\mathrm{S} 1$ and S2 (1.12 and 0.83, respectively) were higher than $\mathrm{PM}_{2.5-10}$ fractions ( 0.87 and 0.70 , respectively), indicating that the smaller particles contain more organic species, which is consistent with other observations reporting more organics in the smaller SSAs (Quinn et al., 2015).

The [O] / [Na] ratios of sample $\mathrm{S} 1$ are higher than those of sample $\mathrm{S} 2$, and those for particles in the $\mathrm{PM}_{2.5-10}$ fractions of samples $\mathrm{S} 1$ and $\mathrm{S} 2$ (0.77 and 0.68 , respectively) are higher than the $\mathrm{PM}_{1.0-2.5}$ fractions $(0.71$ and 0.66 , respectively). Similar observations were made for $\mathrm{S}$ and $\mathrm{Ca}$, for which the elemental concentration ratios were somewhat higher in sample S1 and in larger size fractions (see Table 1). In addition, the frequencies of encountering particles having higher $[\mathrm{S}] /[\mathrm{Na}]$ or $[\mathrm{Ca}] /[\mathrm{Na}]$ ratios than bulk seawater were significantly higher in the summertime sample and in the larger size fractions (see the encountering frequency data for $\mathrm{S}$ and $\mathrm{Ca}$ in Table 1), indicating that $\mathrm{O}, \mathrm{S}$, and $\mathrm{Ca}$ are interrelated to common sources, which is also supported by the observation of elongated $\mathrm{CaSO}_{4}$ rods in the Raman and $\mathrm{X}$-ray mapping measurements. The enriched $\mathrm{S}$ and $\mathrm{O}$ in the $\mathrm{S} 1$ sample appear to be due to the elevated nss- $\mathrm{SO}_{4}^{2-}$ levels. In the austral summer (November-March) of the Antarctic, higher solar radiation levels and temperatures than the other seasons tend to enhance the phytoplankton activities (as supported by its high chlorophyll $a$ level for sample S1), which enhances the production and emission of oceanic dimethyl sulfide (DMS) (Wagenbach et al., 1998; Preunkert et al., 2008). The volatile DMS in the atmosphere undergoes complex sequences of gas-phase oxidation reactions, generating a range of sulfur-containing products, such as dimethyl sulfoxide (DMSO), methanesulfonic acid (MSA), $\mathrm{SO}_{2}$, and $\mathrm{H}_{2} \mathrm{SO}_{4}$ (Gaston et al., 2010). These oxidized products can condense onto preexisting particles, resulting in the formation of nss$\mathrm{SO}_{4}^{2-}$-containing SSAs. As $\mathrm{CaSO}_{4}$ can efflorescence at very high $\mathrm{RH}$, the nss-SO ${ }_{4}^{2-}$ can combine easily with $\mathrm{Ca}$, as observed in Fig. 1, where the $\mathrm{CaSO}_{4}$ rods are observed more frequently in sample $\mathrm{S} 1$.

$\mathrm{Si}$ is observed for the summertime particles, and more abundantly ([Si] $/[\mathrm{Na}]=0.03$ vs. 0.01$)$ and frequently (encountering frequency $=93.4 \%$ vs. $47.5 \%$ ) in the $\mathrm{PM}_{1.0-2.5}$ 
Table 1. Atomic concentration ratios of the chemical elements to $\mathrm{Na}$ for individual particles in the summertime and wintertime $\mathrm{PM}_{2.5-10}$ and $\mathrm{PM}_{1.0-2.5}$ fractions.

\begin{tabular}{|c|c|c|c|c|c|}
\hline \multicolumn{2}{|l|}{ Sample } & \multicolumn{2}{|c|}{ Summertime sample $\mathrm{S} 1$} & \multicolumn{2}{|c|}{ Wintertime sample S2 } \\
\hline \multicolumn{2}{|c|}{ Size fraction } & $\mathrm{PM}_{1.0-2.5}$ (stage 3 ) & $\mathrm{PM}_{2.5-10}$ (stage 2) & $\mathrm{PM}_{1.0-2.5}$ (stage 3 ) & $\mathrm{PM}_{2.5-10}$ (stage 2$)$ \\
\hline \multirow{2}{*}{\multicolumn{2}{|c|}{$\begin{array}{l}\text { Number of particles analyzed } \\
\text { Average size }(\mu \mathrm{m})\end{array}$}} & 146 & 148 & 154 & 156 \\
\hline & & $2.0( \pm 0.6)$ & $2.9( \pm 1.5)$ & $1.7( \pm 0.8)$ & $3.2( \pm 1.5)$ \\
\hline $\begin{array}{l}\text { Elemental } \\
\text { ratios }\end{array}$ & $\begin{array}{l}\text { Seawater ratios } \\
\text { in atomic conc. }\end{array}$ & \multicolumn{4}{|c|}{ Atomic concentration ratios } \\
\hline$[\mathrm{C}] /[\mathrm{Na}]$ & 0.01 & $1.12( \pm 0.35)$ & $0.87( \pm 0.33)$ & $0.83( \pm 0.33)$ & $0.70( \pm 0.24)$ \\
\hline$[\mathrm{O}] /[\mathrm{Na}]$ & $114.03^{\mathrm{b}}$ & $0.71( \pm 0.23)$ & $0.77( \pm 0.25)$ & $0.66( \pm 0.22)$ & $0.68( \pm 0.24)$ \\
\hline$[\mathrm{Mg}] /[\mathrm{Na}]$ & 0.11 & $0.09( \pm 0.02)$ & $0.11( \pm 0.04)$ & $0.11( \pm 0.03)$ & $0.10( \pm 0.03)$ \\
\hline$[\mathrm{Cl}] /[\mathrm{Na}]$ & 1.16 & $0.98( \pm 0.05)$ & $1.01( \pm 0.05)$ & $1.02( \pm 0.10)$ & $1.04( \pm 0.04)$ \\
\hline$[\mathrm{K}] /[\mathrm{Na}]$ & 0.02 & $0.02( \pm 0.01)$ & $0.02( \pm 0.01)$ & $0.01( \pm 0.01)$ & $0.02( \pm 0.01)$ \\
\hline$[\mathrm{S}] /[\mathrm{Na}]$ & 0.06 & $0.065( \pm 0.015)$ & $0.070( \pm 0.019)$ & $0.058( \pm 0.013)$ & $0.059( \pm 0.016)$ \\
\hline$[\mathrm{Ca}] /[\mathrm{Na}]$ & 0.02 & $0.022( \pm 0.009)$ & $0.027( \pm 0.011)$ & $0.018( \pm 0.029)$ & $0.023( \pm 0.012)$ \\
\hline$[\mathrm{Si}] /[\mathrm{Na}]$ & 0.00 & $0.03( \pm 0.02)$ & $0.01( \pm 0.01)$ & 0.00 & 0.00 \\
\hline \multicolumn{2}{|c|}{$\begin{array}{l}\text { Encountering frequency of } \\
\text { particles with }[\mathrm{S}] /[\mathrm{Na}]>0.06\end{array}$} & $52.7 \%$ & $69.7 \%$ & $43.8 \%$ & $41.9 \%$ \\
\hline \multicolumn{2}{|c|}{$\begin{array}{l}\text { Encountering frequency of } \\
\text { particles with }[\mathrm{Ca}] /[\mathrm{Na}]>0.02\end{array}$} & $48.4 \%$ & $69.7 \%$ & $31.5 \%$ & $48.6 \%$ \\
\hline \multicolumn{2}{|c|}{$\begin{array}{l}\text { Encountering frequency of } \\
\text { particles with }[\mathrm{Si}] /[\mathrm{Na}]>0.00\end{array}$} & $93.4 \%$ & $47.5 \%$ & - & - \\
\hline
\end{tabular}

a Refs.: Haynes (2015), Hara et al. (2005). ${ }^{b}$ The [O] / [Na] value for seawater is not meaningful as $\mathrm{H}_{2} \mathrm{O}$ content in seawater is considered.

fraction than in the $\mathrm{PM}_{2.5-10}$ fraction. As $\mathrm{Si}$ is observed mostly in sample $\mathrm{S} 1$ and more in the smaller size fraction, it appears to be from fragments of silica cell walls of diatoms, a major group of algae and a common type of phytoplankton in the oceans (Litchman and Klausmeier, 2008; Alpert et al., 2015). In the winter, the reduced diatom activities would decrease the emission of Si species into the atmosphere, resulting in the scarce observation of $\mathrm{Si}$ in sample $\mathrm{S} 2$.

In the SSAs of samples $\mathrm{S} 1$ and $\mathrm{S} 2$, only $\mathrm{Cl}$ is depleted compared to bulk seawater $([\mathrm{Cl}] /[\mathrm{Na}]=1.00$ and 1.03 for samples $\mathrm{S} 1$ and S2, respectively, vs. 1.16 for seawater), and the $\mathrm{Cl}$ depletion is somewhat higher for the summertime SSAs than the wintertime and for $\mathrm{PM}_{1.0-2.5}$ fractions than $\mathrm{PM}_{2.5-10}$ fractions, suggesting that $\mathrm{Cl}$ was liberated by the reactions of $\mathrm{NaCl}$ and/or $\mathrm{MgCl}_{2}$ with nss- $\mathrm{SO}_{4}^{2-}$ and/or $\mathrm{CH}_{3} \mathrm{SO}_{3}^{-}$, which are more abundant in the summer, with more depletion for smaller SSAs having a higher surface-tovolume ratio and higher reactivity.

\subsection{Single-particle molecular speciation of Antarctic SSAs using RMS and ATR-FTIR imaging}

Based on low- $Z$ particle EPMA analysis, the $\mathrm{C}, \mathrm{O}, \mathrm{Si}, \mathrm{S}$, and $\mathrm{Ca}$ levels were elevated for the summertime SSAs on a single-particle basis. This quantitative elemental X-ray analysis provides useful information on their morphology, elemental chemical compositions, and mixing states of individual Antarctica SSAs. On the other hand, as low- $Z$ particle
EPMA has a limitation on molecular speciation and hydrogen detection, the RMS and ATR-FTIR imaging techniques were applied in combination for the analysis of the same individual SSAs to investigate their Raman- and IR-active organic and inorganic molecular species. Raman and ATRFTIR techniques are useful because their spectra of organic and inorganic compounds are quite specific, depending on their chemical species, phase, crystallinity, and neighboring environment. In particular, the complicated vibrational spectral patterns observed in the fingerprint region $\left(<1500 \mathrm{~cm}^{-1}\right)$ in the Raman and FTIR spectra can be critically useful for the positive or negative identification of specific organic compounds with the same phase and crystallinity. In addition, the differences in their spectra owing to their different signal generation mechanisms (i.e., scattering vs. absorption of energy) and different selection rules would make the two fingerprint techniques rather complementary (Jung et al., 2014).

\subsubsection{Organic species}

Among the $\sim 250$ individual SSAs of samples S1 and S2 investigated by RMS and ATR-FTIR imaging techniques, the frequently observed organic species are most probably ones containing Mg hydrate salts of alanine (MgAla) and Mg salts of fatty acids (MgFAs).

Figure 4 shows baseline-corrected Raman and ATR-FTIR spectra of two individual summertime SSAs containing mainly two types of MgAla (detailed identification is given 
(a) Type 1

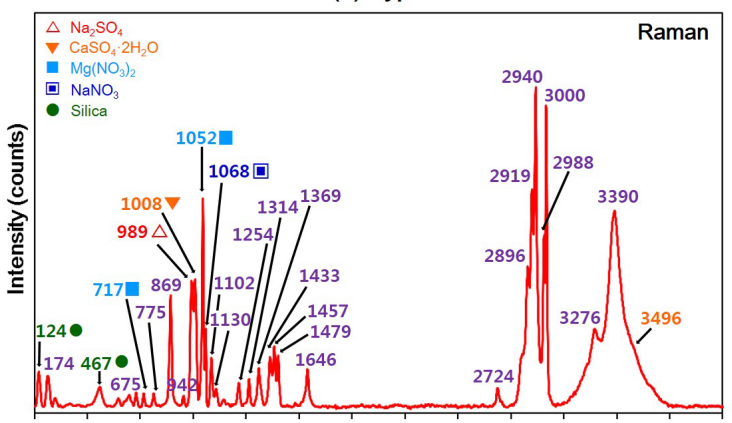

$\begin{array}{llllllll}100 & 400 & 700 & 1000 & 1300 & \begin{array}{l}1600 \\ \text { Raman shift }\left(\mathrm{cm}^{-1}\right)\end{array}\end{array}$

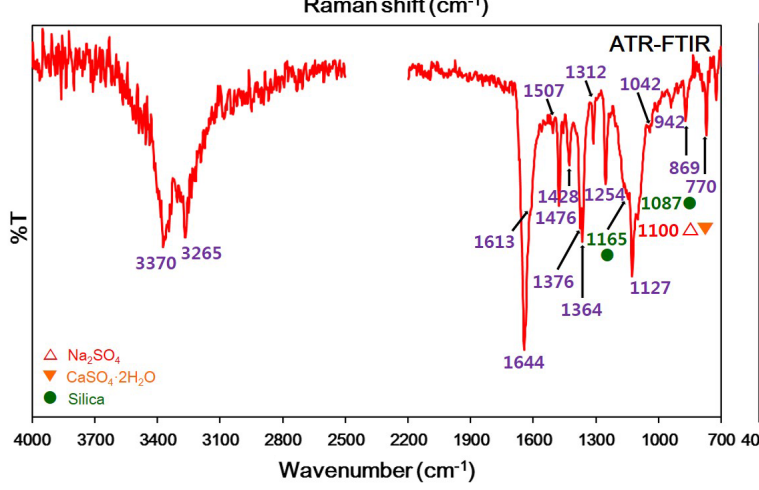

(b) Type 2

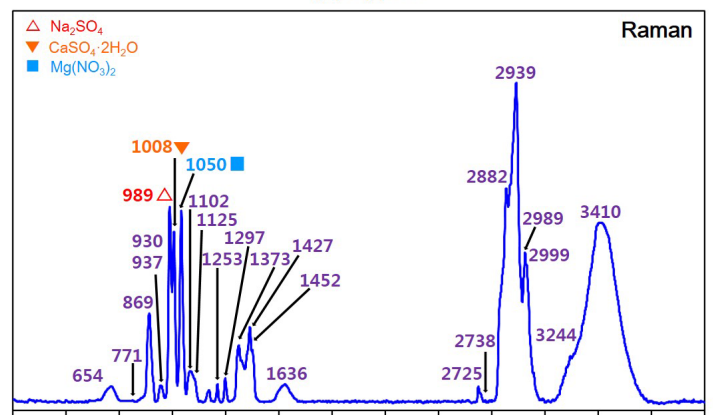

$\begin{array}{llllllll}1900 & 2200 & 2500 & 2800 & 3100 & 3400 & 3700 & 4000\end{array}$ Raman shift $\left(\mathrm{cm}^{-1}\right)$

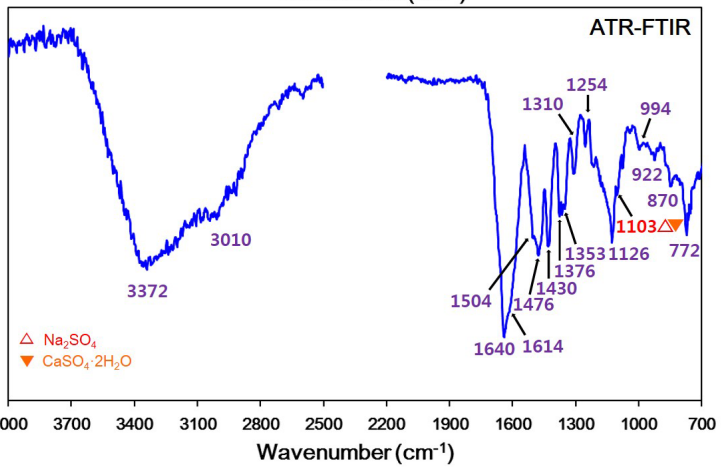

Figure 4. Raman and ATR-FTIR spectra of two typical individual summertime SSAs. The ATR-FTIR data from the $2200-2390 \mathrm{~cm}^{-1}$ region, where the atmospheric $\mathrm{CO}_{2}$ peaks are present, were deleted for clarity.

later) with some inorganic compounds. If several peaks from inorganic compounds (i.e., Raman peaks at 124 and $467 \mathrm{~cm}^{-1}$ for $\mathrm{SiO}_{2}$, at 717 and $1052 \mathrm{~cm}^{-1}$ for $\mathrm{Mg}\left(\mathrm{NO}_{3}\right)_{2}$, at $989 \mathrm{~cm}^{-1}$ for $\mathrm{Na}_{2} \mathrm{SO}_{4}$, at $1008 \mathrm{~cm}^{-1}$ for $\mathrm{CaSO}_{4} \cdot 2 \mathrm{H}_{2} \mathrm{O}$, and at $1068 \mathrm{~cm}^{-1}$ for $\mathrm{NaNO}_{3}$; and ATR-FTIR peaks at 1087 and $1165 \mathrm{~cm}^{-1}$ for $\mathrm{SiO}_{2}$, and $1100 \mathrm{~cm}^{-1}$ for $\mathrm{Na}_{2} \mathrm{SO}_{4}$ and $\mathrm{CaSO}_{4} \cdot 2 \mathrm{H}_{2} \mathrm{O}$ ) are excluded from consideration, the Raman and ATR-FTIR spectra of two types of SSAs are similar except for their different Raman and ATR-FTIR peak shapes. That is, the Raman peaks of crystalline water are sharp at 3276 and $3390 \mathrm{~cm}^{-1}$ for Type 1 SSA, compared to the relatively broad peak at $3410 \mathrm{~cm}^{-1}$ for Type 2 SSA. The C-H vibration Raman peaks of Type 1 SSA are split at $3000 / 2988$ and $2940 / 2919 \mathrm{~cm}^{-1}$, which correspond to the non-split Raman peaks of Type 2 SSA at 2989 and $2939 \mathrm{~cm}^{-1}$. The C-H bending Raman peaks of Type 1 SSA are split into $1433 / 1457 / 1479 \mathrm{~cm}^{-1}$, which correspond to the Raman peaks of Type 2 SSA at $1427 / 1452 \mathrm{~cm}^{-1}$. In the fingerprint region, the characteristic Raman peaks both for Type 1 and 2 SSAs are observed at 869, 1102, 1130, $1254, \sim 1300, \sim 1370$, and $1640 \mathrm{~cm}^{-1}$. Similarly, the ATRFTIR peaks of crystal water are sharp and broad at 3265 and $3370 \mathrm{~cm}^{-1}$ for Type $1 \mathrm{SSA}$ and $3372 \mathrm{~cm}^{-1}$ for Type 2 SSA, respectively, even though the C-H vibration ATR-FTIR peaks are unclear for both types of SSAs. In the ATR-FTIR spectra, the water bending peaks at $\sim 1640 \mathrm{~cm}^{-1}$ are quite strong for both types of SSA, with the peak of Type 1 SSA being much sharper. In the fingerprint region, the characteristic ATR-FTIR peaks for both Type 1 and 2 SSAs at 770, 869, $1127,1254,1312, \sim 1360,1376,1428,1476$, and $1507 \mathrm{~cm}^{-1}$ are sharp and broad for the Type 1 and 2 SSAs, respectively. Similar Raman and ATR-FTIR peak patterns of the Type 1 and 2 spectra except for their different peak shapes strongly indicate that they have the same chemical compositions but different crystal structures. As amorphous solids tend to provide broader Raman and ATR-FTIR peaks than crystalline solids (Shebanova and Lazor, 2003; Gouadec and Colomban, 2007; Lutz and Haeuseler, 1999; Yan et al., 2008), the Type 1 and 2 SSAs are most likely crystalline and amorphous solid particles, respectively.

Figure S3 shows the Raman and ATR-FTIR spectra of aerosols generated by the nebulization of a mixture solution of $0.2 \mathrm{M}$ alanine and $0.1 \mathrm{M} \mathrm{MgCl}_{2}$ standard chemicals and collected on $\mathrm{Al}$ foil. All the fresh aerosol particles immediately after nebulization showed the first pair of Raman and ATR-FTIR spectra in Fig. S3 on a single-particle basis, which resemble the Raman and ATR-FTIR spectra shown in Fig. 4b when the Raman and ATR-FTIR peaks from the inorganic compounds are excluded. In particular, the ATR-FTIR spectra in Figs. 4b and S3 appear similar. When the aerosols were measured $\sim 1$ year later after the generated aerosols had been sealed in a plastic box and stored in a desiccator, approximately half of the generated aerosols showed a second pair of Raman and ATR-FTIR spectra, as shown in Fig. S3, 
and the other half showed a third pair. The third spectra pair appears similar to those in Fig. $4 \mathrm{a}$ for a crystalline solid SSA, whereas the second spectra pair appears to be between the first and third spectra pairs in Fig. S3, strongly suggesting that the fresh aerosols generated from the alanine and $\mathrm{MgCl}_{2}$ solution are a somewhat amorphous form of MgAla, whereas the second and third spectra pairs suggest a more crystalline nature of MgAla. The Raman peaks of the aerosols generated at 3409 and $1637 \mathrm{~cm}^{-1}$ are not from free water because these Raman peaks were unchanged even at very low RH $(<5 \%)$ when the in situ Raman measurement was performed by changing the $\mathrm{RH}$ in the hygroscopic measurement system described in a previous study (Gupta et al., 2015). This means that the intensities and shapes of the Raman peaks should be reduced and changed, respectively, when the RH is decreased to a very low level if these peaks are from free water. In other words, the peaks are from the hydrate crystal water bound for divalent $\mathrm{Mg}$ compounds as the narrow peak shapes and peak positions resemble those of the known spectra of $\mathrm{MgCl}_{2} \cdot 6 \mathrm{H}_{2} \mathrm{O}$ and $\mathrm{MgCl}_{2} \cdot 4 \mathrm{H}_{2} \mathrm{O}$ solids with hydrate crystal water (Gupta et al., 2015). Divalent $\mathrm{Ca}$ ions are also present in seawater. However, based on X-ray and Raman mapping results, $\mathrm{Ca}$ ions are mostly combined with inorganic $\mathrm{SO}_{4}^{2-}$ and slightly present in regions where organic moieties are.

Based on a comparison of the Raman and ATR-FTIR spectra obtained for the summertime SSAs and aerosols generated from the mixture solution of standard alanine and $\mathrm{MgCl}_{2}$, the organic species are ones containing mainly the $\mathrm{Mg}$ hydrate salts of alanine (MgAla), even though their precise molecular formula and the other possible minor components could not be confirmed. The Raman spectrum, which is the same as that of crystalline MgAla, was also observed for nascent SSAs produced using breaking waves, even though their molecular species were not identified (Ault et al., 2013b; Wang et al., 2015). In a previous study, the ATR-FTIR spectra were obtained from other summertime Antarctica SSAs, which appear very similar to that of amorphous MgAla (Maskey et al., 2011). Interestingly, almost all the ATR-FTIR spectra obtained in the previous work were for amorphous MgAla, whereas among the 254 individual SSAs analyzed in this study, the number of crystalline and amorphous MgAla-containing SSAs were 246 and 8, respectively, based on their Raman and ATR-FTIR spectra. How crystallization from SSAs occurred to form these organic $\mathrm{Mg}$ hydrate salts in the Antarctic environment is unclear because crystalline salts could not be made under very dry conditions and by oven-drying overnight. On the other hand, somewhat crystalline salts were encountered from the generated aerosol sample stored for $\sim 1$ year in a desiccator. Some efficient efflorescence seeds should be present in the Antarctic SSAs, which have much more complicated chemical compositions than the mixture solution of pure alanine and $\mathrm{MgCl}_{2}$. The identification of an accurate molecular formula and structure of MgAla and an investigation of the crystallization mechanism requires further study.

The dominant dissolved amino acid in seawater is glycine followed by alanine and aspartic acid or serine (Ogawa and Tanoue, 2003; Dittmar et al., 2001). In seawater, MgAla species would be present as dissolved organic matter (DOM) in the form of alanine before being airborne. On the other hand, based on the Raman and ATR-FTIR spectra of standard powdery glycine and aerosol particles nebulized from aqueous mixtures of glycine/ $/ \mathrm{MgCl}_{2}$ and glycine/alanine/ $/ \mathrm{MgCl}_{2}$ as well as other common target chemicals for organic matter in nascent SSAs such as sodium dodecyl sulfate, a dipeptide of alanine and glycine, a polypeptide, and lipopolysaccharides, which are shown in Fig. S4, it is clear that MgAlacontaining SSAs are composed of mainly alanine with negligible glycine and other target chemicals. As the Raman and ATR-FTIR sensitivities for alanine and glycine are comparable and the same Raman spectrum for MgAla was also observed in the nascent SSAs produced from breaking waves, there must be some unknown processes for the generation of MgAla-containing SSAs from seawater.

Figure 5 shows the baseline-corrected Raman and ATRFTIR spectra of two individual SSAs of sample S2 containing mainly MgFAs and both MgAla and MgFAs. As shown in Fig. S5, the Raman spectra of powdery standard Mg palmitate, palmitic acid, Mg stearate, and stearic acid appear similar except for minor differences in relative peak intensities, which is not sufficient to identify the organic species having the Raman spectrum of Fig. 5a. On the other hand, $\mathrm{Mg}$ palmitate/stearate and palmitic/stearic acids have very different ATR-FTIR spectra as shown in Fig. S5. Owing to their additional strong peaks at $\sim 1700 \mathrm{~cm}^{-1}$ for the -COOH functional group and very different peak patterns in the fingerprint region of $700-1600 \mathrm{~cm}^{-1}$, palmitic/stearic acids can be clearly distinguishable from $\mathrm{Mg}$ palmitate/stearate. The ATR-FTIR spectrum of $\mathrm{Mg}$ palmitate is different from that of $\mathrm{Mg}$ stearate based on the strong hydrate peaks at 3374 and $3256 \mathrm{~cm}^{-1}$ for $\mathrm{Mg}$ palmitate and the clearly different peak patterns in the wavenumber range, $1200-1600 \mathrm{~cm}^{-1}$, between those of $\mathrm{Mg}$ palmitate and stearate. Figure $\mathrm{S} 6$ shows the ATR-FTIR spectra of Mg palmitate, $\mathrm{Mg}$ stearate, a mixture of $\mathrm{Mg}$ palmitate and stearate (by $3: 1$ ), and MgFAcontaining SSA, where the spectra of the mixture particle and the SSA match quite well, indicating that the exemplar Antarctic SSA is a mixture of $\mathrm{Mg}$ palmitate and stearate. Therefore, this type of SSA is called the Mg salts of fatty acids (MgFAs) above. The same Raman spectrum as that of MgFAs was also observed for the nascent SSAs produced using breaking waves (Ault et al., 2013b; Wang et al., 2015). As the pKa of palmitic and steric acids is 4.95 , the palmitic/stearic acid moieties degraded from the lipids would exist predominantly as surfactant palmitate/stearate in SSML and/or on sea surface and would crystallize as their Mg salts after the MgFA-containing SSAs were airborne by bubble busting. 
(a) MgFAs-containing

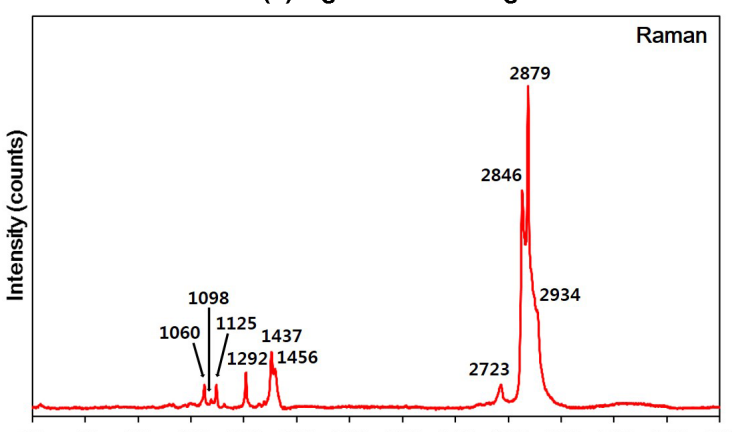

$\begin{array}{llllllllllllll}100 & 400 & 700 & 1000 & 1300 & 1600 & 1900 & 2200 & 2500 & 2800 & 3100 & 3400 & 3700 & 4000\end{array}$ Raman shift $\left(\mathrm{cm}^{-1}\right)$

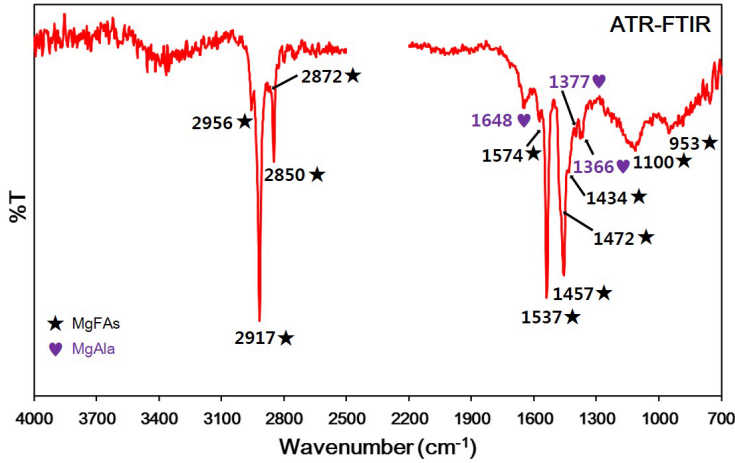

(b) Both MgAla and MgFAs-containing
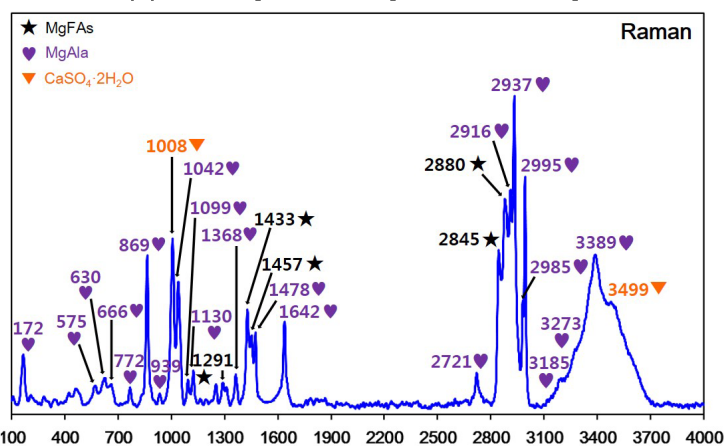
Raman shift $\left(\mathrm{cm}^{-1}\right)$

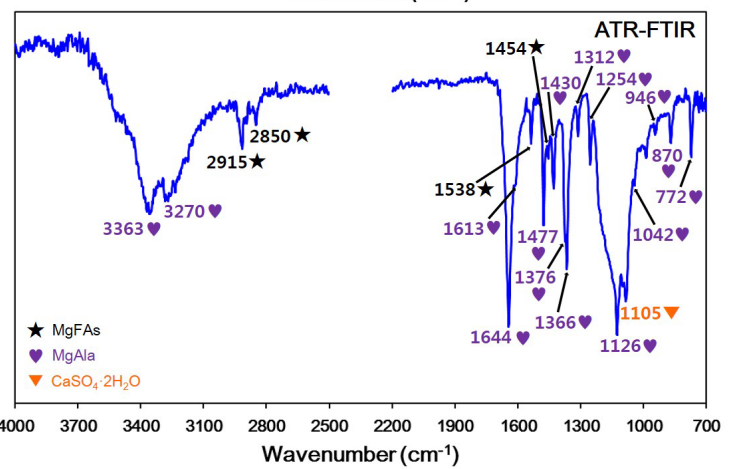

Figure 5. Raman and ATR-FTIR spectra of two typical individual wintertime SSAs. The ATR-FTIR data from the $2200-2390 \mathrm{~cm}^{-1} \mathrm{region}$ where atmospheric $\mathrm{CO}_{2}$ peaks are present, were deleted for clarity.

\subsubsection{Inorganic species}

The Raman and IR active inorganic species observed in the Antarctic SSAs were $\mathrm{CaSO}_{4}, \mathrm{Na}_{2} \mathrm{SO}_{4}, \mathrm{NaNO}_{3}, \mathrm{Mg}\left(\mathrm{NO}_{3}\right)_{2}$, $\mathrm{NH}_{4} \mathrm{NO}_{3}, \mathrm{CH}_{3} \mathrm{SO}_{3} \mathrm{Mg}$ (Mg methanesulfonate), and $\mathrm{SiO}_{2}$, and their standard Raman and ATR-FTIR spectra are shown in Fig. S7. The inorganic species present in the SSAs could be identified clearly by matching both the Raman and ATRFTIR spectra of the SSAs with those of the standard inorganic compounds, even though the inorganic species in the SSAs were observed together with organic species so that the Raman and ATR-FTIR peaks of inorganic species sometimes appear weak compared to those of organic species. On the other hand, even under that situation, RMS is a powerful tool as the Raman peaks of inorganic compounds are quite useful for identifying them.

\subsection{Single-particle characterization of Antarctic SSAs using RMS and ATR-FTIR imaging}

Table 2 shows relative encountering frequencies of the organic and inorganic species for $\sim 250$ individual Antarctic SSAs. The encountering frequency of certain chemical species was determined by counting the number of individual SSAs containing the species, regardless of its content, as the Raman and ATR-FTIR spectral data were used for qualitative molecular speciation. Based on $\mathrm{X}$-ray analysis, $\mathrm{C}$ and
$\mathrm{O}$ were present in all the analyzed Antarctic SSAs. Indeed, organic salt species were detected for all the particles of samples $\mathrm{S} 1$ and $\mathrm{S} 2$, showing that organic species are ubiquitously present, even in supermicron SSAs. As shown in Table 2, organic salt species were categorized into three groups containing (i) MgAla, (ii) MgFAs, and (iii) mixtures of the two organic salts. The Raman and IR active inorganic salts were always observed together with organic salt species, so that the relative encountering frequencies of inorganic species are shown in each organic group.

All the particles of sample S1 contained only MgAla together with other inorganic species. In particular, $\mathrm{CaSO}_{4}$ and $\mathrm{Na}_{2} \mathrm{SO}_{4}$ are mixed almost internally with MgAla (for $\mathrm{PM}_{1.0-2.5}$ and $\mathrm{PM}_{2.5-10}$ fractions, the encountering frequencies of $\mathrm{CaSO}_{4}$ were 98.3 and $92.9 \%$, respectively, and those of $\mathrm{Na}_{2} \mathrm{SO}_{4}$ were 98.3 and $88.6 \%$, respectively), indicating that $\mathrm{SO}_{4}^{2-}$ is mostly in the form of a $\mathrm{CaSO}_{4}$ and $\mathrm{Na}_{2} \mathrm{SO}_{4}$ mixture. Although a N X-ray signal was not detected, probably due to the small amount of $\mathrm{NO}_{3}^{-}$present in the Antarctic SSAs, $\mathrm{Mg}\left(\mathrm{NO}_{3}\right)_{2}$ and $\mathrm{NaNO}_{3}$ were frequently observed in samples S1 and S2 using Raman and ATR-FTIR techniques. The nitrate in seawater can be generated by the photoammonification process, which transforms dissolved organic nitrogen (DON) to labile inorganic nitrogen, mainly ammonium $\left(\mathrm{NH}_{4}^{+}\right.$) (Kitidis et al., 2006; Aarnos et al., 2012; Xie et al., 2012; Rain-Franco et al., 2014; Paulot et al., 2015), followed by the microbial oxidation of ammonium into ni- 
Table 2. Relative encountering frequencies (in \%) of the organic and inorganic species of individual summertime and wintertime SSAs.

\begin{tabular}{|c|c|c|c|c|c|}
\hline \multirow{3}{*}{ Organic salt group } & \multirow{2}{*}{$\begin{array}{l}\text { Sample } \\
\text { Size fraction }\end{array}$} & \multicolumn{2}{|c|}{ Summertime sample S1 } & \multicolumn{2}{|c|}{ Wintertime sample S2 } \\
\hline & & $\begin{array}{r}\mathrm{PM}_{1.0-2.5} \\
\text { (stage 3) }\end{array}$ & $\begin{array}{r}\mathrm{PM}_{2.5-10} \\
\text { (stage 2) }\end{array}$ & $\begin{array}{r}\mathrm{PM}_{1.0-2.5} \\
\text { (stage 3) }\end{array}$ & $\begin{array}{r}\mathrm{PM}_{2.5-10} \\
(\text { stage } 2 \text { ) }\end{array}$ \\
\hline & $\begin{array}{l}\text { Number of particles } \\
\text { analyzed }\end{array}$ & 58 & 70 & 64 & 62 \\
\hline \multirow{8}{*}{$\begin{array}{l}\text { Containing Mg hydrate } \\
\text { salts of alanine (MgAla) }\end{array}$} & Overall & 100.0 & 100.0 & 76.6 & 33.9 \\
\hline & With $\mathrm{CaSO}_{4}$ & 98.3 & 92.9 & 76.6 & 29.0 \\
\hline & With $\mathrm{Na}_{2} \mathrm{SO}_{4}$ & 98.3 & 88.6 & 18.8 & 4.8 \\
\hline & With $\mathrm{Mg}\left(\mathrm{NO}_{3}\right)_{2}$ & 51.7 & 77.1 & 32.8 & 22.6 \\
\hline & With $\mathrm{NH}_{4} \mathrm{NO}_{3}$ & 3.4 & - & 6.3 & - \\
\hline & With $\mathrm{NaNO}_{3}$ & - & 38.6 & 7.8 & 14.5 \\
\hline & $\begin{array}{l}\text { With } \mathrm{Mg} \\
\text { methanesulfonate }\end{array}$ & 3.4 & & & \\
\hline & With $\mathrm{SiO}_{2}$ & 46.6 & 27.1 & 6.3 & 1.6 \\
\hline \multirow{3}{*}{$\begin{array}{l}\text { Containing Mg salts } \\
\text { of fatty acids (MgFAs) }\end{array}$} & Overall & & & 1.6 & 11.3 \\
\hline & With $\mathrm{CaSO}_{4}$ & & & 1.6 & 6.4 \\
\hline & With $\mathrm{Mg}\left(\mathrm{NO}_{3}\right)_{2}$ & & & 1.6 & 3.2 \\
\hline Containing both & Overall & & & 21.9 & 54.8 \\
\hline \multirow[t]{6}{*}{ MgAla and MgFAs } & With $\mathrm{CaSO}_{4}$ & & & 20.3 & 53.2 \\
\hline & With $\mathrm{Na}_{2} \mathrm{SO}_{4}$ & & & 7.8 & 3.2 \\
\hline & With $\mathrm{Mg}\left(\mathrm{NO}_{3}\right)_{2}$ & & & 9.4 & 50.0 \\
\hline & With $\mathrm{NH}_{4} \mathrm{NO}_{3}$ & & & 1.6 & - \\
\hline & With $\mathrm{NaNO}_{3}$ & & & 4.7 & 12.9 \\
\hline & With $\mathrm{SiO}_{2}$ & & & 1.6 & 1.6 \\
\hline
\end{tabular}

trate $\left(\mathrm{NO}_{3}^{-}\right)$by nitrifying bacteria (Carlucci et al., 1970; Hovanec and Delong, 1996; Smith et al., 2014; Tolar et al., 2016). As the photoammonification depends on solar radiations, the ammonium and nitrate production would be enhanced in the summer with a higher solar radiation level. Indeed, as shown in Table 2, nitrates are more frequently observed in summertime sample $\mathrm{S} 1$ than wintertime sample S2. For the $\mathrm{PM}_{1.0-2.5}$ and $\mathrm{PM}_{2.5-10}$ fractions of sample $\mathrm{S} 1$, the overall encountering frequencies of $\mathrm{Mg}\left(\mathrm{NO}_{3}\right)_{2}$ are 51.7 and $77.1 \%$, respectively, and those of $\mathrm{NaNO}_{3}$ are 0.0 and $38.6 \%$, respectively, where the $\mathrm{NO}_{3}^{-}$moiety was observed more in the $\mathrm{PM}_{2.5-10}$ fraction. The reason why the $\mathrm{NO}_{3}^{-}$moiety is more abundant in the $\mathrm{PM}_{2.5-10}$ fraction is unclear. The encountering frequencies of $\mathrm{SiO}_{2}$ are 46.6 and $27.1 \%$ in the $\mathrm{PM}_{1.0-2.5}$ and $\mathrm{PM}_{2.5-10}$ fractions of sample $\mathrm{S} 1$, respectively. $\mathrm{SiO}_{2}$, which would be from fragments of silica cell walls of diatoms, appears to be in colloidal form because $\mathrm{SiO}_{2}$ species are not water-soluble and were observed more in the $\mathrm{PM}_{1.0-2.5}$ fraction than in $\mathrm{PM}_{2.5-10}$. A small number of $\mathrm{Mg}$ methanesulfonate was observed only in the $\mathrm{PM}_{1.0-2.5}$ fraction of sample S1. Higher phytoplankton activities in the summer enhance the production and emission of oceanic DMS, resulting in the production of MSA, which is a strong acid that can exist as an anion in seawater and is observed as Mg salts in SSAs, even though its encountering frequency is not high compared to other sulfates.
A significant portion of SSAs of sample S2 contain only MgAla (overall 76.6 and $33.9 \%$ for $\mathrm{PM}_{1.0-2.5}$ and $\mathrm{PM}_{2.5-10}$ fractions, respectively) (see Table 2). Considering the encountering frequencies of MgAla mixed with MgFAs (21.9 and $54.8 \%$ for $\mathrm{PM}_{1.0-2.5}$ and $\mathrm{PM}_{2.5-10}$ fractions, respectively), MgAla is also almost ubiquitous in sample S2 (overall 98.5 and $88.7 \%$ for $\mathrm{PM}_{1.0-2.5}$ and $\mathrm{PM}_{2.5-10}$ fractions, respectively). MgFAs mixed internally with MgAla were encountered significantly in sample S2 (overall 23.5 and $66.1 \%$ for $\mathrm{PM}_{1.0-2.5}$ and $\mathrm{PM}_{2.5-10}$ fractions, respectively). For the $\mathrm{PM}_{1.0-2.5}$ and $\mathrm{PM}_{2.5-10}$ fractions, the encountering frequencies of $\mathrm{CaSO}_{4}$ are 98.5 and $88.6 \%$ overall, respectively, whereas those of $\mathrm{Na}_{2} \mathrm{SO}_{4}$ are 26.6 and $8.0 \%$, respectively, indicating that $\mathrm{SO}_{4}^{2-}$ is mostly in the form of $\mathrm{CaSO}_{4}$. For the $\mathrm{PM}_{1.0-2.5}$ and $\mathrm{PM}_{2.5-10}$ fractions, the overall encountering frequencies of $\mathrm{Mg}\left(\mathrm{NO}_{3}\right)_{2}$ are 43.8 and $75.8 \%$, respectively, and those of $\mathrm{NaNO}_{3}$ are 12.5 and $27.4 \%$, respectively, where the $\mathrm{NO}_{3}^{-}$moiety was also observed more in the $\mathrm{PM}_{2.5-10}$ fraction. $\mathrm{SiO}_{2}$ was encountered much less frequently, 7.9 and $3.2 \%$ in the $\mathrm{PM}_{1.0-2.5}$ and $\mathrm{PM}_{2.5-10}$ fractions, respectively, compared to those of sample S1 (i.e., 46.6 and $27.1 \%$, respectively). The observation of a higher encountering frequency of $\mathrm{SiO}_{2}$ in sample $\mathrm{S} 1$ is consistent with that of X-ray analysis, where the detection of the Si X-ray signal was 70.1 and $0.7 \%$ for samples $\mathrm{S} 1$ and $\mathrm{S} 2$, respectively. 
The relative encountering frequency data for the organic and inorganic species of samples $\mathrm{S} 1$ and $\mathrm{S} 2$ clearly show their different chemical compositional features. MgAlacontaining SSAs are predominant for samples S1 and S2. The MgFAs were not observed in sample S1, but were observed in sample S2, mostly as internal mixtures with MgAla. As alanine is water-soluble and anions of fatty acids are surfactants, they would be present mostly at the bulk seawater and SSML/sea surface, respectively, before becoming airborne. Therefore, alanine- and fatty acid-containing SSAs are expected to be airborne through jet- and film-drop production during bubble busting, resulting in the generation of supermicron and submicron SSAs, respectively (de Leeuw et al., 2011; Quinn et al., 2015). In this study, supermicron SSAs were investigated for which MgAla is almost ubiquitous in samples $\mathrm{S} 1$ and S2, indicating that the supermicron SSAs were generated as jet drops. As MgFAs were observed mostly together with MgAla in sample S2, the MgFAcontaining SSAs originating from film drops might agglomerate with MgAla-containing supermicron SSAs in the air.

In a recent mesocosm experiment, the organic matter in SSAs generated from the wave braking of natural seawater was monitored for 29 days after adding nutrients at the beginning of the experiment during which two phytoplankton blooms occurred (Wang et al., 2015). The aliphatic-rich organic matter level in the nascent SSAs was enhanced during the first bloom, whereas the oxygen-rich organic matter level increased at the early period of the experiment before the first bloom and remained somewhat constant thereafter, including the second bloom period. The MgAla and MgFAs observed in this study are the aliphatic-rich and oxygen-rich organic matters in their work, respectively, because the Raman spectra of MaAla and MgFAs are the same as those for oxygenand aliphatic-rich organic matters and the $\mathrm{O} / \mathrm{C}$ atomic ratios of alanine, palmitic, and stearic acids are $0.67,0.13$, and 0.11 (in their work, $\mathrm{O} / \mathrm{C}>0.5$ for oxygen-rich organic matters and $<0.25$ for aliphatic-rich organic matters). In this study, the summertime Antarctic SSAs contain oxygen-rich organic matter, such as MgAla, whereas the wintertime SSAs contain aliphatic-rich organic matter, such as MgFAs as well as oxygen-rich organic matter. The aliphatic-rich organic matter was observed only during the first bloom in the mesocosm experiment, whereas supermicron MgFA-containing SSAs were encountered only in the wintertime sample $\mathrm{S} 2$ collected during no bloom event, suggesting that the chemical features of organic matter in nascent SSAs cannot be correlated consistently with the phytoplankton activity. As microalgae can produce more lipid and less protein under environmental stress, such as limited nutrients and low temperature (Wu et al., 2011; Yu et al., 2009; Olson and Ingram, 1975), MgFAs, which were biodegraded from lipid, may be observed more frequently in the wintertime oligotrophic Antarctic Ocean with a lower temperature.

\section{Summary}

X-ray analysis of a single-particle analysis showed that the supermicron summertime and wintertime Antarctic samples have different elemental chemical compositions, even though all the individual particles analyzed were SSAs; i.e., contents of $\mathrm{C}, \mathrm{O}, \mathrm{Ca}, \mathrm{S}$, and $\mathrm{Si}$ are more elevated, whereas $\mathrm{Cl}$ is more depleted for the summertime sample $\mathrm{S} 1$ than for the wintertime sample S2. The combined application of RMS and ATR-FTIR imaging to the same individual SSAs made the molecular speciation of the observed organic and inorganic species feasible. Based on qualitative analysis of the chemical species present in the individual SSAs by RMS and ATR-FTIR imaging, different organic species were observed in samples $\mathrm{S} 1$ and $\mathrm{S} 2$; i.e., $\mathrm{Mg}$ hydrate salts of alanine are predominant in the $\mathrm{S} 1$ and $\mathrm{S} 2$ samples, whereas $\mathrm{Mg}$ salts of fatty acids mixed internally with $\mathrm{Mg}$ hydrate salts of alanine are significant in sample $\mathrm{S} 2$. Although $\mathrm{CaSO}_{4}$ is encountered significantly in both samples $\mathrm{S} 1$ and $\mathrm{S} 2$, the other inorganic species, such as $\mathrm{Na}_{2} \mathrm{SO}_{4}, \mathrm{NaNO}_{3}, \mathrm{Mg}\left(\mathrm{NO}_{3}\right)_{2}, \mathrm{SiO}_{2}$, and $\mathrm{CH}_{3} \mathrm{SO}_{3} \mathrm{Mg}$, were encountered more significantly in sample $\mathrm{S} 1$, suggesting that they reflect the high phytoplankton activity in the summer.

In this study, there were new observations regarding the chemical compositional features of nascent Antarctic SSAs and some of them need to be explained in further studies. First, although just two SSA samples, having a high oceanic chlorophyll $a$ level contrast, collected in the summer and winter, were investigated, their chemical compositional features were clearly different in terms of their chemical species and/or levels of inorganic and organic moieties. However, it is not clear whether the different compositional features are due to the different sampling seasons or biological activities. To answer this question, a study for a total of 29 Antarctic aerosol samples collected during December 2011 and September 2012 when the oceanic chlorophyll $a$ levels are in the range of $0.07-13.38 \mu \mathrm{g} \mathrm{L}^{-1}$ is underway. Second, even the supermicron SSAs were enriched significantly by organic matter, and thus the effects of organic matter in supermicron SSAs need to be considered more seriously in a radiative forcing model study. Third, based on the Raman and ATR-FTIR measurements, the organic moieties in SSAs are believed to be present mainly as the salt forms of surprisingly simple organic compounds, such as alanine and palmitic/stearic acids, which appear to be the biodegraded final products from proteins and lipids, respectively, but the reason why alanine and palmitic/stearic acids are predominant as the final products is unclear. In addition, the Mg hydrate salts of alanine are almost ubiquitous in both the summertime and wintertime supermicron SSAs, but the Mg salts of fatty acids were encountered only in the wintertime supermicron SSAs, which will require further study to better understand the generation processes of Antarctic SSAs. 


\section{Data availability}

The raw and processed data for this article are available upon request to the corresponding author.

\section{The Supplement related to this article is available online at doi:10.5194/acp-16-13823-2016-supplement.}

Acknowledgements. This study was supported by Basic Science Research Programs through the National Research Foundation of Korea (NRF) funded by the Ministry of Education, Science, and Technology (NRF-2015R1A2A1A09003573).

Edited by: T. Bertram

Reviewed by: two anonymous referees

\section{References}

Aarnos, H., Ylöstalo, P., and Vähätalo, A. V.: Seasonal phototransformation of dissolved organic matter to ammonium, dissolved inorganic carbon, and labile substrates supporting bacterial biomass across the Baltic Sea, J. Geophys. Res., 117, G01004, doi:10.1029/2010JG001633, 2012.

Alpert, P. A., Kilthau, W. P., Bothe, D. W., Radway, J. C., Aller, J. Y., and Knopf, D. A.: The influence of marine microbial activities on aerosol production: A laboratory mesocosm study, J. Geophys. Res., 120, 8841-8860, doi:10.1002/2015JD023469, 2015.

Ault, A. P., Moffet, R. C., Baltrusaitis, J., Collins, D. B., Ruppel, M. J., Cuadra-Rodriguez, L. A., Zhao, D., Guasco, T. L., Ebben, C. J., Geiger, F. M., Bertram, T. H., Prather, K. A., and Grassian, V. H.: Size-Dependent Changes in Sea Spray Aerosol Composition and Properties with Different Seawater Conditions, Environ. Sci. Technol., 47, 5603-5612, 2013a.

Ault, A. P., Zhao, D., Ebben, C. J., Tauber, M. J., Geiger, F. M., Prather, K. A., and Grassian, V. H.: Raman microspectroscopy and vibrational sum frequency generation spectroscopy as probes of the bulk and surface compositions of size-resolved sea spray aerosol particles, Phys. Chem. Chem. Phys., 15, 6206-6212, $2013 b$.

Bates, T. S., Quinn, P. K., Frossard, A. A., Russell, L. M., Hakala, J., Petäjä, T., Kulmala, M., Covert, D. S., Cappa, C. D., Li, S. M., Hayden, K. L., Nuaaman, I., McLaren, R., Massoli, P., Canagaratna, M. R., Onasch, T. B., Sueper, D., Worsnop, D. R., and Keene, W. C.: Measurements of ocean derived aerosol off the coast of California, J. Geophys. Res.-Atmos., 117, D00V15, doi:10.1029/2012JD017588, 2012.

Biancato, D., Ceccato, D., Chiminello, F., and Mittner, P.: MicroPIXE and principal component analysis in a study of internal mixing phenomena in Antarctic coastal aerosol, Nucl. Instrum. Meth. B, 249, 561-565, 2006.

Carlucci, A. F., Hartwig, E. O., and Bowes, P. M.: Biological production of nitrite in seawater, Mar. Biol., 7, 161-166, 1970. de Leeuw, G., Andreas, E. L., Anguelova, M. D., Fairall, C. W., Lewis, E. R., O’Dowd, C., Schulz, M., and Schwartz, S. E.: Production flux of sea spray aerosol, Rev. Geophys., 49, RG2001, doi:10.1029/2010RG000349, 2011.

Dittmar, T., Fitznar, H. P., and Kattner, G.: Origin and biogeochemical cycling of organic nitrogen in the eastern Arctic Ocean as evident from D- and L-amino acids, Geochim. Cosmochim. Ac., 65, 4103-4114, 2001.

Eom, H.-J., Jung, H.-J., Sobanska, S., Chung, S.-G., Son, Y.-S., Kim, J.-C., Sunwoo, Y., and Ro, C.-U.: Iron speciation of airborne subway particles by the combined use of energy dispersive electron probe X-ray microanalysis and Raman microspectrometry, Anal. Chem., 85, 10424-10431, 2013.

Gaston, C. J., Pratt, K. A., Qin, X., and Prather, K. A.: Real-time detection and mixing state of methanesulfonate in single particles at an inland urban location during a phytoplankton bloom, Environ. Sci. Technol., 44, 1566-1572, 2010.

Gouadec, G. and Colomban, P.: Raman Spectroscopy of Nanomaterials: How Spectra Relate to Disorder, Particle Size and Mechanical Properties, Prog. Cryst. Growth Ch., 53, 1-56, 2007.

Gupta, D., Eom, H.-J., Cho, H.-R., and Ro, C.-U.: Hygroscopic behavior of $\mathrm{NaCl}-\mathrm{MgCl}_{2}$ mixture particles as nascent seaspray aerosol surrogates and observation of efflorescence during humidification, Atmos. Chem. Phys., 15, 11273-11290, doi:10.5194/acp-15-11273-2015, 2015.

Hara, K., Osada, K., Kido, M., Matsunaga, K., Iwasaka, Y., Hashida, G., and Yamanouchi, T.: Variations of constituents of individual sea-salt particles at Syowa station, Antarctica, Tellus, 57B, 230-246, 2005.

Hara, K., Iwasaka, Y., Wada, M., Ihara, T., Shiba, H., Osada, K., and Yamanouchi, T.: Aerosol constituents and their spatial distribution in the free troposphere of coastal Antarctic regions, J. Geophys. Res., 111, D15216, doi:10.1029/2005JD006591, 2006.

Hara, K., Osada, K., Yabuki, M., and Yamanouchi, T.: Seasonal variation of fractionated sea-salt particles on the Antarctic coast, Geophys. Res. Lett., 39, L18801, doi:10.1029/2012GL052761, 2012.

Hara, K., Osada, K., and Yamanouchi, T.: Tethered balloon-borne aerosol measurements: seasonal and vertical variations of aerosol constituents over Syowa Station, Antarctica, Atmos. Chem. Phys., 13, 9119-9139, doi:10.5194/acp-13-9119-2013, 2013.

Hara, K., Nakazawa, F., Fujita, S., Fukui, K., Enomoto, H., and Sugiyama, S.: Horizontal distributions of aerosol constituents and their mixing states in Antarctica during the JASE traverse, Atmos. Chem. Phys., 14, 10211-10230, doi:10.5194/acp-1410211-2014, 2014.

Haynes, W. M.: CRC Handbook of Chemistry and Physics, 96th Edition, CRC Press, Boca Raton, Florida, 14-18, 2015.

Hovanec, T. A. and DeLong, E. F.: Comparative Analysis of Nitrifying Bacteria Associated with Freshwater and Marine Aquaria, Appl. Environ. Microb., 62, 2888-2896, 1996.

Hu, Q.-H., Xie, Z.-Q., Wang, X.-M., Kang, H., He, Q.-F., and Zhang, P.: Secondary organic aerosols over oceans via oxidation of isoprene and monoterpenes from Arctic to Antarctic, Sci. Rep., 3, 2280, doi:10.1038/srep02280, 2013.

Jung, H.-J., Eom, H.-J., Kang, H.-W., Moreau, M., Sobanska, S., and Ro, C.-U.: Combined use of quantitative ED-EPMA, Raman microspecrometry, and ATR-FTIR imaging techniques for the analysis of individual particles, Analyst, 139, 3949-3960, 2014. 
Kerminen, V.-M., Teinilä, K., and Hillamo, R.: Chemistry of seasalt particles in the summer Antarctic atmosphere, Atmos. Environ., 34, 2817-2825, 2000.

Kitidis, V., Uher, G., Upstill-Goddard, R. C., Mantoura, R. F. C., Spyres, G., and Woodward, E. M. S.: Photochemical production of ammonium in the oligotrophic Cyprus Gyre (Eastern Mediterranean), Biogeosciences, 3, 439-449, doi:10.5194/bg-3439-2006, 2006.

Laskina, O.: Physicochemical properties of mineral dust and sea spray aerosols, PhD thesis, Iowa City, Iowa, 129-149, 2015.

Lee, S. H., Joo, H. M., Joo, H., Kim, B. K., Song, H. J., Jeon, M., and Kang, S.-H.: Large contribution of small phytoplankton at Marian Cove, King George Island, Antarctica, based on longterm monitoring from 1996 to 2008, Polar Biol., 38, 207-220, 2015.

Litchman, E. and Klausmeier, C. A.: Trait-Based Community Ecology of Phytoplankton, Annu. Rev. Ecol. Evol. S., 39, 615-639, 2008.

Lutz, H. D. and Haeuseler, H.: Infrared and Raman spectroscopy in inorganic solids research, J. Mol. Struct., 511-512, 69-75, 1999.

Maskey, S., Geng, H., Song, Y.-C., Hwang, H., Yoon, Y.-J., Ahn, K.-H., and Ro, C.-U.: Single-Particle Characterization of Summertime Antarctic Aerosols Collected at King George Island Using Quantitative Energy-Dispersive Electron Probe X-ray Microanalysis and Attenuated Total Reflection Fourier TransformInfrared Imaging Techniques, Environ. Sci. Technol., 45, 62756282, 2011.

O’Dowd, C. D., Facchini, M. C., Cavalli, F., Ceburnis, D., Mircea, M., Decesari, S., Fuzzi, S., Yoon, Y. J., and Putaud, J.-P.: Biogenically driven organic contribution to marine aerosol, Nature, 431, 676-680, 2004.

Ogawa, H. and Tanoue, E.: Dissolved Organic Matter in Oceanic Waters, J. Oceanogr., 59, 129-147, 2003.

Olson, G. J. and Ingram, L. O.: Effects of temperature and nutritional changes on the fatty acids of Agmenellum quadruplicatum, J. Bacteriol., 124, 373-379, 1975.

Paulot, F., Jacob, D. J., Johnson, M. T., Bell, T. G., Baker, A. R., Keene, W. C., Lima, I. D., Doney, S. C., and Stock, C. A.: Global oceanic emission of ammonia: Constraints from seawater and atmospheric observations, Global Biogeochem. Cy., 29, 11651178, 2015.

Prather, K. A., Bertram, T. H., Grassian, V. H., Deane, G. B., Stokes, M. D., DeMott, P. J., Aluwihare, L. I., Palenik, B. P., Azam, F., Seinfeld, J. H., Moffet, R. C., Molina, M. J., Cappa, C. D., Geiger, F. M., Roberts, G. C., Russell, L. M., Ault, A. P., Baltrusaitis, J., Collins, D. B., Corrigan, C. E., Cuadra-Rodriguez, L. A., Ebben, C. J., Forestieri, S. D., Guasco, T. L., Hersey, S. P., Kim, M. J., Lambert, W. F., Modini, R. L., Mui, W., Pedler, B. E., Ruppel, M. J., Ryder, O. S., Schoepp, N. G., Sullivan, R. C., and Zhao, D.: Bringing the ocean into the laboratory to probe the chemical complexity of sea spray aerosol, P. Natl. Acad. Sci. USA, 19, 7550-7555, 2013.

Préndez, M., Wachter, J., Vega, C., Flocchini, R. G., Wakayabashi, P., and Morales, J. R.: $\mathrm{PM}_{2.5}$ aerosols collected in the Antarctic Peninsula with a solar powered sampler during austral summer periods, Atmos. Environ., 43, 5575-5578, 2009.

Preunkert, S., Jourdain, B., Legrand, M., Udisti, R., Becagli, S., and Cerri, O.: Seasonality of sulfur species (dimethyl sulfide, sulfate, and methanesulfonate) in Antarctica: In- land versus coastal regions, J. Geophys. Res., 113, D15302, doi:10.1029/2008JD009937, 2008.

Quinn, P. K., Bates, T. S., Schulz, K. S., Coffman, D. J., Frossard, A. A., Russell, L. M., Keene, W. C., and Kieber, D. J.: Contribution of sea surface carbon pool to organic matter enrichment in sea spray aerosol, Nat. Geosci., 7, 228-232, 2014.

Quinn, P. K., Collins, D. B., Grassian, V. H., and Prather, K. A.: Chemistry and Related Properties of Freshly Emitted Sea Spray Aerosol, Chem. Rev., 115, 4383-4399, 2015.

Rain-Franco, A., Muñoz, C., and Fernandez, C.: Ammonium Production off Central Chile $\left(36^{\circ} \mathrm{S}\right)$ by Photodegradation of Phytoplankton-Derived and Marine Dissolved Organic Matter, Plos One, 26, e100224, doi:10.1371/journal.pone.0100224, 2014.

Rinaldi, M., Decesari, S., Finessi, E., Giulianelli, L., Carbone, C., Fuzzi, S., O’Dowd, C. D., Ceburnis, D., and Facchini, M. C.: Primary and Secondary Organic Marine Aerosol and Oceanic Biological Activity: Recent Results and New Perspectives for Future Studies, Adv. Meteorol., 310682, 1-10, doi:10.1155/2010/310682, 2010.

Ro, C.-U., Osán, J., and Van Grieken, R.: Determination of low-Z elements in individual environmental particles using windowless EPMA, Anal. Chem., 71, 1521-1528, 1999.

Ro, C.-U., Osán, J., Szalóki, I., de Hoog, J., Worobiec, A., and Van Grieken, R.: A Monte Carlo program for quantitative electroninduced X-ray analysis of individual particles, Anal. Chem., 75, 851-859, 2003.

Ro, C.-U., Hwang, H., Kim, H., Chun, Y., and Van Grieken, R.: Single-particle characterization of four "Asian dust" samples collected in Korea, using low-Z particle electron probe X-ray microanalysis, Environ. Sci. Technol., 39, 1409-1419, 2005.

Schindelholz, E., Risteen, B. E., and Kelly, R. G.: Effect of Relative Humidity on Corrosion of Steel under Sea Salt Aerosol Proxies, J. Electrochem. Soc., 161, 460-470, 2014.

Schloss, I. R., Wasilowska, A., Dumont, D., Almandoz, G. O., Hernando, M. P., Michaud-Tremblay, C.-A., Saravia, L., Rzepecki, M., Monien, P., Monien, D., Kopczyńska, E. E., Bers, A. V., and Ferreyra, G. A.: On the phytoplankton bloom in coastal waters of southern King George Island (Antarctica) in January 2010: An exceptional feature?, Limnol. Oceanogr., 59, 195-210, 2014.

Shaw, G. E.: Antarctic aerosols: A review, Rev. Geophys., 26, 89112, doi:10.1029/RG026i001p00089, 1988.

Shebanova, O. N. and Lazor, P. J.: Raman spectroscopic study of magnetite $\left(\mathrm{FeFe}_{2} \mathrm{O}_{4}\right)$ : a new assignment for the vibrational spectrum, Solid State Chem., 174, 424-430, 2003.

Smith, J. M., Chavez, F. P., and Francis, C. A.: Ammonium Uptake by Phytoplankton Regulates Nitrification in the Sunlit Ocean, Plos One, 24, e108173, doi:10.1371/journal.pone.0108173, 2015.

Sobanska, S., Hwang, H., Choël, M., Jung, H.-J., Eom, H.-J., Kim, H., Barbillat, J., and Ro, C.-U.: Investigation of the Chemical Mixing State of Individual Asian Dust Particles by the Combined Use of Electron Probe X-ray Microanalysis and Raman Microspectrometry, Anal. Chem., 84, 3145-3154, 2012.

Song, Y.-C., Ryu, J., Malek, M. A., Jung, H.-J., and Ro, C.-U.: Chemical speciation of individual airborne particles by the combined use of quantitative energy-dispersive electron probe X-ray microanalysis and attenuated total reflection Fourier transforminfrared imaging techniques, Anal. Chem., 82, 7987-7998, 2010. 
Song, Y.-C., Eom, H.-J., Jung, H.-J., Malek, M. A., Kim, H. K., Geng, H., and Ro, C.-U.: Investigation of aged Asian dust particles by the combined use of quantitative ED-EPMA and ATR-FTIR imaging, Atmos. Chem. Phys., 13, 3463-3480, doi:10.5194/acp-13-3463-2013, 2013.

Tolar, B. B., Ross, M. J., Wallsgrove, N. J., Liu, Q., Aluwihare, L. I., Popp, B. N., and Hollibaugh, J. T.: Contribution of ammonia oxidation to chemoautotrophy in Antarctic coastal waters, ISME J., 10, 2605-2619, 2016.

Van Dalen, G., Heussen, P. C. M., Den Adel, R., and Hoeve, R. B. J.: Attenuated total internal reflection infrared microscopy of multilayer plastic packaging foils, Appl. Spectrosc., 61, 593-602, 2007.

Vekemans, B., Janssens, K., Vincze, L., Adams, F., and Van Espen, P.: Analysis of X-ray spectra by iterative least squares (AXIL): New developments, X-Ray Spectrom., 23, 278-285, 1994.

Wagenbach, D., Ducroz, F., Mulvaney, R., Keck, L., Minikin, A., Legrand, M., Hall, J. S., and Wolff, E. W.: Sea-salt aerosol in coastal Antarctic regions, J. Geophys. Res., 103, 10961-10974, 1998.

Wang, X., Sultana, C. M., Trueblood, J., Hill, T. C. J., Malfatti, F., Lee, C., Laskina, O., Moore, K. A., Beall, C. M., McCluskey, C. S., Cornwell, G. C., Zhou, Y., Cox, J. L., Pendergraft, M. A., Santander, M. V., Bertram, T. H., Cappa, C. D., Azam, F., DeMott, P. J., Grassian, V. H., and Prather, K. A.: Microbial Control of Sea Spray Aerosol Composition: A Tale of Two Blooms, ACS Cent. Sci., 1, 124-131, 2015.
Wu, H., Volponi, J. V., Oliver, A. E., Parikh, A. N., Simmons, B. A., and Singh, S.: In vivo lipidomics using single-cell Raman spectroscopy, P. Natl. Acad. Sci. USA, 108, 3809-3814, 2011.

Xiao, H.-S., Dong, J.-L., Wang, L.-Y., Zhao, L.-J., Wang, F., and Zhang, Y.-H.: Spatially resolved micro-Raman observation on the phase separation of effloresced sea salt droplets, Environ. Sci. Technol., 42, 8698-8702, 2008.

Xie, H., Bélanger, S., Song, G., Benner, R., Taalba, A., Blais, M., Tremblay, J.-É., and Babin, M.: Photoproduction of ammonium in the southeastern Beaufort Sea and its biogeochemical implications, Biogeosciences, 9, 3047-3061, doi:10.5194/bg-9-30472012, 2012.

Yan, J., Asami, T., and Kuriyagawa, T.: Nondestructive measurement of machining-induced amorphous layers in single-crystal silicon by laser micro-Raman spectroscopy, Precis. Eng., 32, 186-195, 2008.

Yu, E. T., Zendejas, F. J., Lane, P. D., Gaucher, S., Simmons, B. A., and Lane, T. W.: Triacylglycerol accumulation and profiling in the model diatoms Thalassiosira pseudonana and Phaeodactylum tricornutum (Baccilariophyceae) during starvation, J. Appl. Phycol., 21, 669-681, 2009. 